\title{
KETERAMPILAN KOLABORASI MAHASISWA TEKNOLOGI PENDIDIKAN DALAM MATA KULIAH KEWIRAUSAHAAN BERBASIS PROYEK
}

\author{
Putri Siti Nadhiroh, Pujiriyanto \\ Kurikulum dan Teknologi Pendidikan, FIP, UNY \\ e-mail: putri.siti2015@student.uny.ac.id,pujiriyanto@uny.ac.id
}

\begin{abstract}
Abstrak
Penelitian ini bertujuan untuk mendeskripsikan, (1) Proses pembelajaran Mata Kuliah Kewirausahaan berbasis proyek pada mahasiswa Teknologi Pendidikan sebagai strategi pengembangan keterampilan kolaborasi; (2) Keterampilan kolaborasi mahasiswa Teknologi Pendidikan. Penelitian ini menggunakan metode kualitatif yang berjenis studi kasus. Teknik pengumpulan data menggunakan observasi, wawancara, dan dokumentasi. Hasil penelitian menunjukkan bahwa kegiatan pembelajaran kewirausahaan sudah dilakukan dengan baik melalui 6 tahapan, yaitu penyajian masalah, perencanaan kerja, penjadwalan, pembuatan proyek, penilaian, dan evaluasi. Keterampilan kolaborasi mahasiswa menunjukkan hasil yang baik, (1) Mahasiswa sudah mampu berkomunikasi dengan baik; (2) Mahasiswa tertib dalam kehadiran; (3) Mampu memimpin anggotanya; (4) Mahasiswa memiliki kesadaran tinggi untuk menyelesaikan proyek; (5) Kerjasama dilakukan dengan baik; (6) Mahasiswa menggunakan sumber terpercaya; (7) Mahasiswa mampu menyesuaikan diri dengan perubahan; (8) Mampu mengontrol emosi; dan (9) Sembilan dari sebelas kelompok lolos terdanai PMW 2019. Namun ada beberapa temuan indikator yang belum maksimal: (1) Mahasiswa tidak membuat peraturan; (2) Kurang percaya diri; dan (3) Pengorganisasian kinerja tidak dilakukan secara rinci.
\end{abstract}

Kata Kunci: Keterampilan kolaborasi, pembelajaran berbasis proyek, mata kuliah kewirausahaan

\section{COLLABORATION SKILLS OF EDUCATION TECHNOLOGY STUDENTS IN ENTREPRENEURSHIP PROJECT BASED LEARNING}

\begin{abstract}
This study aims to describe, (1) The learning process of project-based Entrepreneurship Courses in Educational Technology students as a strategy for developing collaboration skills; (2) Collaboration skills of Educational Technology students. This research uses a qualitative method that is a type of case study. Data collection techniques using observation, interviews, and documentation. The results showed that the entrepreneurial learning activities had been carried out well through 6 stages, namely problem presentation, work planning, scheduling, project making, assessment, and evaluation. Student collaboration skills show good results, (1) Students are able to communicate well; (2) Students are orderly in attendance; (3) Able to lead members; (4) Students have high awareness to complete the project; (5) Cooperation is done well; (6) Students use trusted sources; (7) Students are able to adjust to changes; (8) Able to control emotions; and (9) Nine out of eleven groups qualify for PMW 2019. However, there are some findings of indicators that have not been maximized: (1) Students do not make regulations; (2) Lack of confidence; and (3) Organizing performance is not carried out in detail.
\end{abstract}

Keywords: Collaboration skills, project-based learning, entrepreneurship subjects

\section{PENDAHULUAN}

Pendidikan abad ke-21 memberi penekanan terhadap kesiapan Sumber Daya Manusia untuk menghadapi era revolusi industri 4.0. Hal ini sejalan dengan tujuan Pendidikan Nasional abad 21 untuk mewujudkan cita-cita bangsa, menjadikan rakyat Indonesia makmur dengan kedudukan setara dengan bangsa lain dalam perkembangan global, dengan cara membentuk dan menciptakan Sumber Daya Manusia yang berkualitas, mandiri, berkemauan, serta berkemampuan dalam mewujudkan citacitanya (BSNP, 2010: 39).

Berkaitan dengan hal tersebut, maka pendidikan menjadi salah satu pilar utama untuk membantu menciptakan dan meningkatkan performa Sumber Daya Manusia (SDM) yang siap menghadapi tantangan dan perubahan yang terjadi saat ini dengan berbekal keterampilan abad 21 (21 ${ }^{\text {st }}$ Century Skills). USbased Partnership for 21 st Century Skills (P21), mengidentifikasi kompetensi yang paling penting dan dibutuhkan di abad ke-21 yaitu 
"Four Cs"- critical thinking, communication, collaboration, dan creativity. Sejalan dengan hal tersebut, melalui Permendikbud Nomor 20 Tahun 2016 tentang Standar Kompetensi Lulusan, pemerintah mendorong agar kemampuan serupa dimiliki oleh setiap lulusan, meliputi keterampilan berpikir dan bertindak kreatif, produktif, kritis, mandiri, kolaboratif, dan komunikatif (Kemendikbud, 2016a: 8).

Berdasarkan keterampilan-keterampilan yang dibutuhkan di abad 21, salah satu keterampilan yang penting adalah kolaborasi. Kolaborasi merupakan aktivitas bekerja sama dalam menuju satu tujuan bersama, dalam kolaborasi terdapat setidaknya 3 elemen atau komponen, yaitu komunikasi, kerja sama, dan responsive (Hesse et al., 2015: 38). Ali Mustadi (2014a: 87), "in a collaborative learning, there is no competition or rivalry among the students but mutual learning", dalam pembelajaran kolaboratif ditegaskan bahwa tidak ada persaingan di antara pebelajar. Pembelajaran kolaboratif dilakukan berdasarkan model yang menjelaskan bahwa pengetahuan dapat dibuat dalam suatu populasi yang anggotanya aktif berinteraksi satu sama lain, saling berbagi pengalaman, dan saling mengambil peran asimetri atau peran yang berbeda (Ali Mustadi, 2014b: 20). Berkaitan dengan hal tersebut, hasil penelitian PISA (Programme for International Students Assessment), menyatakan bahwa keterampilan kolaborasi merupakan keterampilan yang penting untuk mendorong keberhasilan seseorang dan juga dapat meningkatkan aspek sosial. Keterampilanketerampilan tersebut dapat ditumbuhkan melalui kegiatan pembelajaran pada jenjang pendidikan rendah ataupun pendidikan tinggi.

Dalam pendidikan tinggi, mata kuliah kewirausahaan menjadi salah satu mata kuliah yang mampu menjembatani mahasiswa untuk dapat survive dalam kehidupan abad 21. Pendidikan kewirausahaan juga menjadi salah satu mata kuliah yang strategis untuk mengembangkan keterampilan kolaborasi mahasiswa.

Idealnya, pendidikan saat ini harus mampu menumbuhkan keterampilan pada diri pebelajar untuk dapat menciptakan SDM yang berkompeten. Perguruan tinggi seharusnya mampu menerapkan pembelajaran yang bersifat inovatif untuk mengembangkan kompetensi mahasiswa, dalam hal ini terutama melalui pembelajaran kewirausahaan. Namun hal ini masih belum sesuai dengan harapan, karena kondisi di lapangan saat ini masih banyak masalah yang terjadi. Berdasarkan studi pendahuluan, pembelajaran kewirausahaan di Fakultas Ilmu Pendidikan dari tahun ke tahun masih sama, bersifat konvensional, mengacu pada hasil, dan belum dapat menciptakan kemandirian mahasiswa serta keterampilan kolaborasi mahasiswa. Kegiatan pembelajaran kewirausahaan yang belum ideal menjadi salah satu alasan banyaknya pengangguran terdidik, mahasiswa belum seutuhnya memiliki kemandirian dan keinginan berwirausaha. Hal tersebut juga menjadi alasan sulitnya menumbuhkan keterampilan kolaborasi mahasiswa. Terbukti ketika mahasiswa diberikan tugas kelompok oleh dosen, dalam satu kelompok selalu saja ada salah satu diantara anggota yang bekerja lebih banyak atau mendominasi, sedangkan yang lainnya lebih banyak diam dan tidak banyak berpartisipasi/ berkontribusi dalam kerja kelompok. Permasalahan lain yang menunjukkan kurangnya keterampilan kolaborasi adalah adanya mahasiswa yang mangkir dari tugas, enggan menjadi pemimpin dalam kelompok, terjadi permusuhan dalam kelompok, dan sebagainya.

Begitu pun dengan kegiatan pembelajaran di perguruan tinggi, dalam era ini hendaknya pembelajaran ditransformasikan ke orientasi yang dapat membekali mahasiswa dengan skill yang dibutuhkan untuk menghadapi tantangan kehidupan saat ini. Hal ini menjadi alasan mengapa model pembelajaran yang tepat harus diterapkan dalam kegiatan pembelajaran.

Uniknya, Program Studi Teknologi Pendidikan ini menjadi satu-satunya program studi yang sudah menggunakan model pembelajaran yang bersifat inovatif dalam mata kuliah kewirausahaan. Salah satu model pembelajaran yang dapat meningkatkan skill mahasiswa dalam abad 21 ini yang digunakan 
oleh dosen Teknologi Pendidikan adalah model pembelajaran $\mathrm{PjBL}$, yaitu model pembelajaran yang dapat meningkatkan kerjasama anggota kelompok. Model PjBL dikembangkan berdasarkan paham pembelajaran konstruktivis, penerapan model ini mampu mendukung mahasiswa untuk membangun pengetahuannya dalam konteks pengalamannya sendiri. Konstruktivis menitikberatkan pada upaya mempersiapkan mahasiswa untuk dapat memecahkan masalahnya sendiri dalam situasi yang serba tidak menentu serta dalam perubahan zaman yang terjadi begitu cepat.

Berdasarkan hasil studi pendahuluan menunjukkan bahwa kegiatan pembelajaran mata kuliah kewirausahaan pada mahasiswa Prodi Teknologi Pendidikan ini didesain dengan model pembelajaran berbasis proyek yang diarahkan ke Program Mahasiswa Wirausaha (PMW) sebagai bagian dari strategi pendidikan di perguruan tinggi untuk memfasilitasi mahasiswa dalam berwirausaha secara berkolaborasi. Hasil wawancara terhadap beberapa mahasiswa di berbagai program studi Fakultas Ilmu Pendidikan, menunjukkan bahwa inovasi kegiatan pembelajaran kewirausahaan yang dilakukan di Prodi Teknologi Pendidikan ini menjadi berbeda dengan mata kuliah kewirausahaan yang dilakukan oleh prodi lainnya yang sebagian besar masih bersifat konvensional dan belum diintegrasikan dengan Program Mahasiswa Wirausaha.

Kegiatan pembelajaran mata kuliah kewirausahaan pada Prodi Teknologi Pendidikan ini didesain dengan model PjBL dengan tujuan untuk meningkatkan prestasi Prodi Teknologi Pendidikan dalam salah satu program kemahasiswaan UNY, yaitu Program Mahasiswa Wirausaha (PMW). Dalam pembelajaran yang didesain dengan model $\mathrm{PjBL}$, mahasiswa bekerja secara kolaboratif dengan sesama mahasiswa Teknologi Pendidikan ataupun dengan mahasiswa di luar Prodi Teknologi Pendidikan (terdiri dari 2-4 orang dalam satu kelompok), sehingga dalam satu kelas terbentuk 11 kelompok. Kerja kolaboratif ini bertujuan untuk mencapai goal dalam proyek PMW, dengan kerja kolaboratif terbuki bahwa pembelajaran kewirausahaan ini mampu membuat prestasi yang baik. Hal ini ditunjukkan dengan data dari http://kwu.kemahasiswaan.uny.ac.id/ yang menunjukkan bahwa terdapat 9 dari 11 kelompok mahasiswa Prodi Teknologi Pendidikan lolos didanai dalam program kemahasiswaan PMW (Prograam Mahasiswa Wirausaha). Hal ini menunjukkan prestasi yang baik karena hampir 98\% dari keseluruhan kelompok dalam kelas kewirausahaan di Prodi Teknologi Pendidikan dapat lolos dalam pengajuan proposal PMW hingga mendapat pendanaan dari UNY.

Berdasar uraian di atas, maka peneliti tertarik melakukan penelitian dan kajian secara mendalam kepada mahasiswa Teknologi Pendidikan angkatan 2017 Universitas Negeri Yogyakarta dalam kegiatan pembelajaran mata kuliah kewirausahaan yang saat ini sudah diinovasikan dengan model pembelajaran berbasis proyek (Project Based Learning) yang terintegrasi dengan program kemahasiswaan PMW serta mampu meningkatkan prestasi dalam program tersebut yang erat kaitannya dengan kerja kolaboratif yang dilakukan oleh mahasiswa Teknologi Pendidikan.

\section{METODE PENELITIAN}

\section{Jenis Penelitian}

Penelitian ini menggunakan pendekatan kualitatif dengan jenis penelitian yang digunakan adalah studi kasus.

\section{Waktu dan Tempat Penelitian}

Penelitian ini dilakukan pada semester genap 2018/ 2019 selama 10 minggu, dimulai dari pertengahan awal Bulan Februari 2019 hingga awal Bulan Mei 2019. Penelitian ini dilakukan di Fakultas Ilmu Penidikan Universitas Negeri Yogyakarta.

\section{Subjek dan Objek Penelitian}

Objek penelitian ini adalah: (1) Strategi pengembangan keterampilan kolaborasi dalam mata kuliah kewirausahaan berbasis proyek yang meliputi 6 tahapan: (a) Penyajian masalah; (b) Perencanaan kerja; (c) Penjadwalan; (d) 
Pembuatan proyek dan monitoring; (e) Penilaian; dan (d) Evaluasi. (2) Keterampilan kolaborasi mahasiswa Teknologi Pendidikan dalam pembelajaran kewirausahaan berbasis proyek, meliputi: (a) Komunikasi; (b) Pembuatan peraturan dan kesepakatan; (c) Kepemimpinan; (d) Manajemen waktu; (e) Pengorganisasian kinerja; (f) Kerjasama; dan (g) Tanggungjawab.

Peneliti menggunakan teknik purposive sampling untuk mendapatkan informasi yang dibutuhkan. Adapun subjek dalam penelitian ini adalah 11 kelompok mahasiswa Teknologi Pendidikan dan dosen pengampu Mata Kuliah Kewirausahaan.

\section{Prosedur}

Prosedur yang digunakan dalam penelitian ini dilakukan dengan mengecek data yang diperoleh dari berbagai sumber. Data didisplay, dikategorikan, dideskripsikan, kemudian dianalisis untuk memperolah kesimpulan.

\section{Teknik Pengumpulan Data dan Instrumen} Pengumpulan Data

Pengumpulan data dalam penelitian ini menggunakan observasi, wawancara, dan dokumentasi.

\section{Teknik Analisis Data}

Penelitian ini menggunakan jenis analisis data model Miles, Huberman, \& Saldana (2014) aktivitas dalam analisis data model ini adalah data reduction, data display, dan conclusion drawing/verification.

\section{a. Data Reduction}

Miled dan Huberman (2014: 10), "Data condensation refers to the process of selecting data, focusing, simplifying, abstracting, and transforming the data that appear in written-up field notes or transciptions". Kondensasi data dilakukan dengan proses menyeleksi, memfokuskan, menyederhanakan, mengabstraksikan, dan mentransformasi data yang ada pada catatan lapangan ataupun transkip wawancara dalam penelitian.

b. Data Display
Penyajian data dalam penelitian kualitatif berbentuk uraian singkat, bagan, hubungan antar kategori, flowchart, dan sejenisnya. Penyajian data kebanyakan dilakukan dalam bentuk teks yang bersifat naratif. Tujuan penyajian data ini adalah untuk memudahkan memahami fenomena yang terjadi, dan merencanakan langkah kerja selanjutnya. Dalam proses ini peneliti menyusun data yang relevan agar dapat menjadi informasi yang bermakna dengan menyajikannya ke dalam tabel.

c. Verification

Tahap verifikasi dalam penelitian kualitatif dilakukan untuk memberikan gambaran dan menjelaskan kesimpulan yang bermakna. Hal yang dapat dilakukan dalam tahap ini adalah: (1) memaknai analisis spesifik; (2) menarik dan menjelaskan kesimpulan secara ringkas. Proses verifikasi dalam penelitian kualitatif juga harus didukung dengan bukti yang valid agar mendapatkan hasil dan kesimpulan yang kredibel.

\section{HASIL PENELITIAN DAN PEMBAHASAN}

Hasil penelitian menyajikan data tentang: (1) Tahapan pembelajaran kewirausahaan berbasis proyek sebagai strategi pengembangan keterampilan kolaborasi mahasiswa Teknologi Pendidikan; (2) Keterampilan kolaborasi mahasiswa Teknologi Pendidikan.

1. Tahapan Pembelajaran Kewirausahaan Berbasis Proyek

a. Penyajian Masalah

Pelaksanaan tahapan penyajian masalah dalam pembelajaran berbasis proyek dilakukan oleh mahasiswa secara berkolaboratif dengan menggali pertanyaanpertanyaan mendalam untuk menemukan permasalahan di lingkungannya. Kemudian, mahasiswa mencari penyelesaian dengan membuat ide-ide kreatif untuk proyek PMW sebagai bagian utama dari tugas dalam mata kuliah kewirausahaan berbasis proyek. Tahapan ini sesuai dengan teori dalam The George Lucas Educational Foundation (2007) yang menyebutkan langkah pertama 
dalam pembelajaran berbasis proyek adalah start with the essential question, pembelajaran berbasis proyek ini dimulai dengan sebuah pertanyaan yang mendalam. Pertanyaan yang digali oleh mahasiswa akan memunculkan sebuah masalah atau situasi yang harus diatasi.

b. Perencanaan Kerja

The George Lucas Educational Foundation (2007) menyebutkan langkah kedua dalam pembelajaran berbasis proyek adalah Design a Plan for Project, kegiatan mendesain rencana suatu proyek ini dilakukan secara berkolaborasi antara mahasiswa dengan dosen. Dalam kegiatan ini dosen melakukan kegiatan-kegiatan sebagai berikut: (1) Mencantumkan aturan dalam pembuatan proyek; (2) Melakukan pemilihan kegiatan pembelajaran; (3) Membuat tujuan kegiatan pembelajaran; (4) Membuat petunjuk-petunjuk yang membimbing kinerja mahasiswa dalam penyelesaian proyek; (5) Mencantumkan alat dan bahan yang dapat diakses oleh mahasiswa untuk membantu penyelesaian proyek.

c. Penjadwalan

Langkah ketiga dalam pembelajaran berbasis proyek adalah Create a Schedule, dalam kaitannya dengan waktu harus bersifat fleksibel, karena perubahan jadwal dapat terjadi kapan saja (The George Lucas Educational Foundation, 2007). Dosen selalu memberikan penjelasan di akhir kegiatan pembelajaran mengenai hal apa saja yang harus diselesaikan dalam waktu satu minggu (satu kali pertemuan). Dosen juga selalu memberikan "alarm" kepada mahasiswa untuk mengingatkan jadwaljadwal atau deadline baik melalui media sosial whatsapp ataupun secara langsung.

d. Pembuatan Proyek dan Monitoring

The George Lucas Educational Foundation (2007) menyebutkan langkah kedua dalam pembelajaran berbasis proyek adalah Monitor the Students and the Progress of the Project. Dalam tahapan ini, mahasiswa Teknologi Pendidikan mengerjakan proyek yaitu pembuatan draf dan proposal PMW, pembuatan prototype produk, pembuatan media promosi dan alat transaksi.

e. Penilaian

Assess the Outcome adalah tahap kelima, yaitu tahap penilaian. Penilaian dilakukan untuk: (1) mendapat umpan balik; (2) membantu dosen mengukur ketercapaian standar; (3) berperan untuk mengevaluasi kemajuan dan kemampuan tiap-tiap mahasiswa; (4) memberikan umpan balik kepada mahasiswa; (5) membantu dosen dalam menyusun perancangan pembelajaran yang lebih efektif (The George Lucas Educational Foundation, 2007). Sesuai dengan teori, dalam tahap ini dilakukan pengumpulan proyek dan bukti-buktinya untuk diberikan umpan balik dari dosen terkait tingkat pemahaman yang sudah dicapai oleh mahasiswa.

f. Evaluasi

Evaluate the Experience, pada akhir proses pembelajaran diperlukan refleksi yang dilakukan oleh dosen maupun mahasiswa. Refleksi dilakukan untuk menilai apa yang sudah dijalankan selama proses pembelajaran dan bagaimana hasilnya (The George Lucas Educational Foundation, 2007). Dalam tahap ini dosen merefleksikan kegiatan pembelajaran kewirausahaan selama satu semester.

\section{Keterampilan Kolaborasi Mahasiswa Teknologi Pendidikan}

a. Komunikasi

Keterampilan komunikasi mengacu pada kemampuan individu untuk berkomunikasi dengan jelas, menggunakan bahasa lisan, tertulis, dan non-verbal, serta berkolaborasi secara efektif dan bertanggung jawab terhadap individu lain dalam kelompok (Pacific Policy Research Center, 2010: 6). Dalam berkomunikasi pada kegiatan pembelajaran kewirausahaan berbasis proyek PMW, mahasiswa menyampaikan pendapat dan pemikirannya dengan baik, melakukan presentasi dengan jelas, dan menunjukkan bahasa tubuh yang baik. Hal ini terjadi dalam kegiatan 
pembuatan proyek dan monitoring hingga kegiatan evaluasi.

b. Pembuatan Peraturan dan Kesepakatan

Greenstein (2012: 28) menjelaskan salah satu indikator dalam keterampilan kolaborasi adalah membuat peraturan dalam kelompok secara bersama-sama. Pembuatan peraturan-peraturan dasar dalam kelompok ini sangat bermanfaat untuk mengantisipasi adanya permasalahan penolakan kerja terhadap anggota kelompok. Dalam proses presentasi hasil kerja pada kegiatan pembelajaran kewirausahan ini, mahasiswa masih banyak yang terlihat memberikan penolakan pada suatu pembagian kerja. Hal ini terjadi karena mahasiswa belum membuat peraturan-peraturan dasar yang mengikat suatu kelompok untuk menaati kesepakatan-kesepakatan tertentu. Selain itu, hal yang erat dengan peraturan dan kesepakatan adalah kehadiran. Barkley, dkk (2012: 107-117), menjelaskan bahwa persoalan kehadiran dapat menjadi masalah utama yang menyebabkan pertikaian dan kecemburuan antar anggota kelompok. Mahasiswa sudah tertib dalam kehadiran dalam pembelajaran kewirausahaan dan juga dalam kerja kolaboratif di luar jam pembelajaran.

c. Kepemimpinan

Salah satu masalah yang biasa terjadi dalam pembelajaran kolaboratif menurut Barkley, dkk (2012: 107-117) adalah tidak adanya mahasiswa yang bersedia menjadi pemimpin, tanpa seseorang yang memberikan semangat dan mengatur atau mengarahkan dalam suatu kelompok, maka tidak akan terjadi kerja yang efektif. Mahasiswa Teknologi Pendidikan dalam pembelajaran kewirausahaan mampu dengan baik membantu anggota kelompoknya dan menjadi pemimpin yang siap bersedia bekerja lebih keras untuk hasil proyek yang efektif dan lebih baik. Mereka banyak memberikan contoh kepada anggotanya.

d. Manajemen Waktu

Buck Institute for Education (1999), menjabarkan salah satu rubrik keterampilan kolaborasi dalam Project Based Learning (PjBL) adalah menetapkan jadwal, menetapkan target waktu pengerjaan dengan baik, dan terus memantau kemajuan serta tujuan bersama. Mahasiswa Teknologi Pendidikan belum menyusun jadwal kerja secara tertata selama satu semester, namun mahasiswa Teknologi Pendidikan masih memiliki kesadaran tinggi dan "alarm" dalam dirinya, kapan mereka harus mengejar deadline dan menyelesaikan proyek-proyeknya, sehingga hal ini menjadi nilai lebih.

e. Pengorganisasian Kinerja

Mahasiswa Teknologi Pendidikan dalam kegiatan pembelajaran kewirausahaan berbasis proyek belum membuat kerangka kerja yang digunakan untuk mengorganisasikan kinerja mereka selama satu semester. Namun mahasiswa mampu dengan baik menaati perintahperintah dari dosen terkait kinerja yang harus diselesaikan. Buck Institute for Education (1999) menyatakan bahwa indikator pengorganisasian kinerja adalah membuat daftar tugas secara mendetail untuk membagi pekerjaan di antara anggota tim.

f. Kerjasama

Secara keseluruhan, hasil penelitian menunjukkan bahwa secara keseluruhan, hasil penelitian menunjukkan bahwa dalam proses presentasi hasil kerja, mahasiswa Teknologi Pendidikan sudah bekerjasama dengan baik, secara garis besar mahasiswa sudah mengerjakan proyek PMW secara bersama-sama selama satu semester, dan akan terus berlanjut setelah dana dari kemahasiswaan UNY turun. Hal ini akan menciptakan kolaborasi yang berkelanjutan diantara mahasiswa. Hal ini sudah sesuai dengan teori yang menyatakan bahwa kolaborasi merupakan aktivitas bekerja bersama untuk mencapai satu tujuan. Salah satu komponen terpenting dalam kolaborasi adalah kerja sama (Hesse, et al., 2015: 38).

g. Tanggungjawab

$\begin{array}{rcrr}\text { Friend } & \& & \text { Cook } & (2010: 8-13) \\ \text { menjelaskan } & \text { salah } & \text { satu } & \text { karakteristik }\end{array}$


keterampilan kolaborasi adalah bahwa kolaborasi tergantung pada tanggung jawab bersama untuk partisipasi dan pengambilan keputusan. Mahasiswa Teknologi Pendidikan dalam pembelajaran kewirausahaan berbasis proyek sudah mampu berpartisipasi dengan baik dalam tahapan penyajian masalah, yaitu mengambil keputusan secara bersama dalam menentukan ide yang akan diajukan dalam proyek PMW. Mahasiswa juga mampu menyelesaikan proyek dengan sungguhsungguh sehingga mampu mencapai goal dalam pendanaan program PMW dengan hasil maksimal yaitu 9 dari 11 kelompok mahasiswa Teknologi Pendidikan lolos didanai PMW.

h. Fleksibel

Bergenson (2017) dalam Century Skills Standrds Rubrics, menjabarkan salah satu rubrik keterampilan kolaborasi adalah fleksibel dan memiliki kemauan untuk saling berkompromi dalam upaya pencapaian tujuan bersama. Sebagian besar mahasiswa Teknologi Pendidikan sudah memiliki sikap yang fleksibel dalam mengatasi suatu perubahan-perubahan yang terjadi. Seperti yang dilakukan beberapa kelompok yang dengan cepat mampu mengganti ide yang sudah matang ke ide lainnya karena segmentasi pasar yang tidak memungkinkan. Mahasiswa juga mampu dengan cepat beradaptasi ketika jadwal pengumpulan proposal PMW berubah. Dalam kaitannya dengan fleksibelitas ini juga didukung dengan kompromi yang baik. Tiap-tiap anggota kelompok mampu dengan baik berkompromi untuk memikirkan solusi dari suatu perubahan yang tidak pasti.

i. Kontrol Emosi

Salah satu indikator keterampilan kolaborasi menurut Greenstein (2012: 28) adalah dapat mengontrol emosi diri sendiri. Dalam penelitian ini, hal yang diamati adalah bagaimana mahasiswa mencari solusi atas permasalahan dengan kepala dingin. Sebagian besar mahasiswa Teknologi Pendidikan sudah mampu mengontrol emosi dengan baik. Ketika terjadi suatu masalah, sebagian besar mahasiswa melakukan mediasi dengan anggota kelompoknya, baik melalui media whatsapp atauun secara langsung. Mahasiswa selalu membahas secara baik-baik mengenai masalah yang dihadapi oleh kelompok.

\section{PENUTUP}

\section{Simpulan}

Berdasarkan hasil penelitian, maka dapat disimpulkan bahwa:

1. Tahapan kegiatan pembelajaran kewirausahaan berbasis proyek sebagai strategi pengembangan keterampilan kolaborasi pada Mahasiswa Teknologi Pendidikan sudah dilakukan dengan baik dengan 6 tahapan, yaitu penyajian masalah, perencanaan kerja, penjadwalan, pembuatan proyek, penilaian, dan evaluasi.

2. Keterampilan kolaborasi mahasiswa Teknologi Pendidikan dalam mata kuliah kewirausahaan berbasis proyek sudah dilakukan dengan baik, hal ini terlihat dari beberapa indikator: (a) Mahasiswa sudah mampu berkomunikasi dengan baik; (b) Mahasiswa tertib dalam kehadiran; (c) Mampu memimpin anggotanya; (d) Mahasiswa memiliki kesadaran tinggi untuk menyelesaikan proyek; (e) Kerjasama dilakukan dengan baik; (f) Mahasiswa menggunakan sumber terpercaya; (g) Mahasiswa mampu menyesuaikan diri dengan perubahan; (h) Mampu mengontrol emosi; (i) Sembilan dari sebelas kelompok lolos terdanai PMW 2019.

\section{Saran}

Berdasarkan simpulan dari penelitian, maka peneliti dapat memberikan saran sebagai berikut:

1. Bagi Dosen

Sebaiknya dosen-dosen lain menggunakan model pembelajaran berbasis proyek yang terintegrasi dengan Program Wirausaha Mahasiswa untuk diterapkan ke dalam mata kuliah kewirausahaan.

2. Bagi Mahasiswa

Akan lebih baik apabila mahasiswa dapat memanfaatkan kegiatan pembelajaran 
kewirausahaan ini dengan lebih maksimal dan berani mengambil keputusan serta risiko dalam menjalankan proyek sudah difasilitasi dengan baik melalui Program Mahasiswa Wirausaha.

\section{DAFTAR PUSTAKA}

BSNP. (2010). Paradigma Pendidikan Nasional Abad XXI. Jakarta: Badan Standar Nasional Pendidikan.

Barkley, E.E., Cross, K.P., \& Major, C.H. (2012). Collaborative Learning Techniques: Teknik-Teknik Pembelajaran Kolaboratif. (Terjemahan Narulita Yusron). Bandung: Penerbit Nusa Media. (Edisi Asli diterbitkan tahun 2005 oleh Jossey-Bass, San Francisco).

Bergenson, T. (2017). 21 $1^{\text {st }}$ Century Skills Standards Rubrics. Washington: State Superintendent of Public Instruction Daryanto. (2012). Pendidikan Kewirausahaan. Yogyakarta: Penerbit Gava Media.

Buck Institute for Education. (1999). Collaboration Rubrics for PBL. Dikutip 22 Maret 2019 dari Collaboration Rubrics for PBL: https://my.pblworks.org/resource/docum ent/6 12 collaboration rubric ccss alig ned

Friend, M. \& Cook, L. (2010). Interactions Collaboration Skill for School Professionals, (Sixth Edition). Merrill: Pearson Education, Inc.

Greenstein, L. (2012). Assessing 21st Century Skills: A Guide to Evaluating Mastery and Authentic Learning. California: Corwin.P21. (2008). 21st Century Skills, Education \& Competitiveness. Washington DC, Partnership for 21st Century Skills.

Hesse, F., et al. (2015). A Framework for Teachable Collaborative Problem Solving Skill. Dalam P. Griffin, \& E.Care (Eds.), Assesment and Teaching of $21^{\text {st }}$ Century Skill: Methods and Approach (pp. 37-56). Dordrecht: Springer.
Kementerian Pendidikan dan Kebudayaan Republik Indonesia (2016a). Salinan Lampiran Peraturan Menteri Pendidikan dan Kebudayaan Nomor 20, Tahun 2016, tentang Standar Kompetensi Lulusan Pendidikan Dasar dan Menengah.

Miles, Mathew B., Huberman, Michael, dan Saldana, Johnny. (2014). Qualitative Data Analysis-Third Edition, London: Sage Publication Ltd.

Mustadi, A. (2014a). Fundamental school reform through lesson study for learning community (LSLC): A study of collaborative learning in Indonesia and Japan. In Proceeding International Conference on Fundamentals and Implementation of Education (ICFIE) (pp. 87-95). Diakses dari https://eprints.uny.ac.id/24993/1/D10.pdf pada 24 Agustus 2019.

Mustadi, A. (2014b). Lesson Study Berbasis Collaborative Learning sebagai Model Pemantapan Kualitas Pendidikan di Sekolah Dasar. Proceeding Seminar Nasional: Pemantapan Implementasi Kurikulum 2013 dalam Pendidikan Sekolah Dasar. Hal. 19-27. Diakses dari https://repository.stkipgetsempena.ac.id/ bitstream/380/1/SEMNAS-DIKDAS2014.pdf pada 24 Agustus 2019.

Pacific Policy Research Center. (2010). 21st Century Skills for Students and Teachers. Honolulu: Kamehameha Schools, Research \& Evaluation Division.

The George Lucas Educational Foundation. (19 Oktober 2007). What's Project-Based Learning About. Diakses pada 30 Januari 2019, dari https://www.edutopia.org/project-basedlearning-guide-description. 